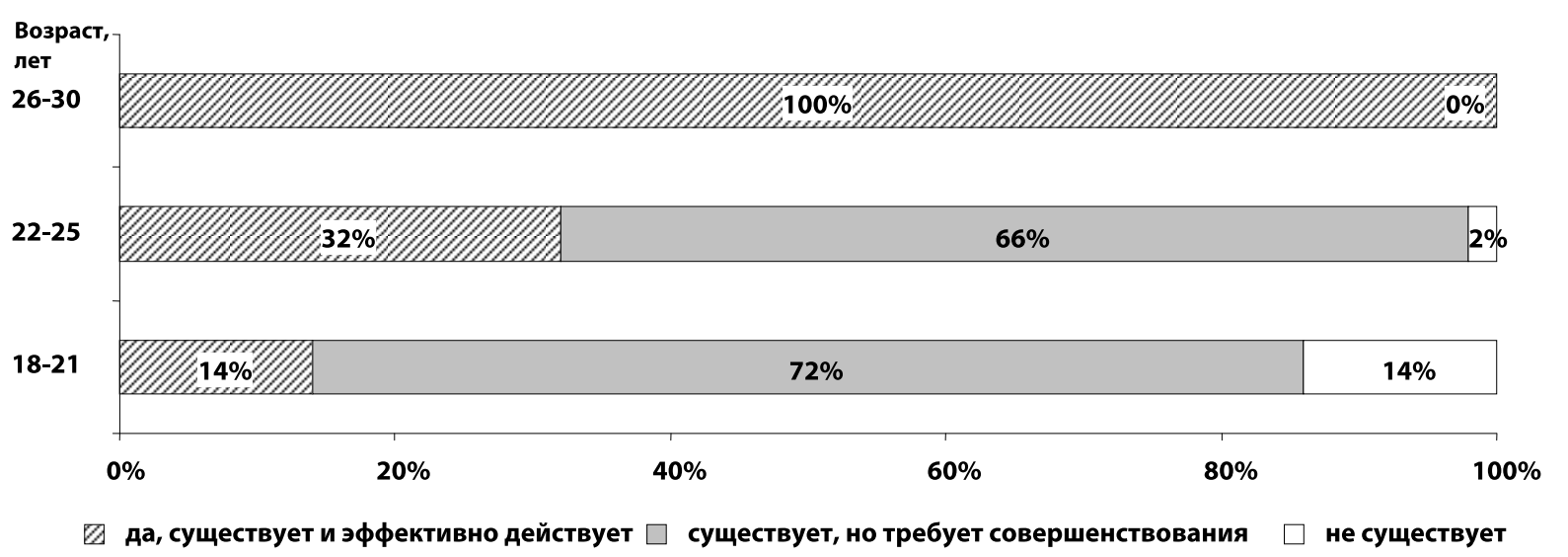

Рис. 3. Влияние возраста респондентов на их мнение о системе работы с молодыми специалистами

ность отношениями с непосредственным руководителем; удовлетворенность возможностью карьерного роста.

Таким образом, в условиях модернизации общества и растущих потребностей к человеческому капиталу работа с молодежью должна стать эффективным инструментом развития и преобразования компании.

Это возможно при условии разработки и последовательной реализации системы работы с молодыми специалистами, ориентированной на прямое вовлечение молодых специалистов в решение как собственных проблем, так и общекорпоративных задач и основанной на приоритетных направлениях Стратегии развития кадрового потенциала компании.

Подобная работа была реализована на Свердловской железной дороге - филиале ОАО «РЖД» и дала конкретные результаты.

Анализ данных о прибытии, использовании и выбытии молодых специалистов показывает положительную динамику доли работающих молодых специалистов в общей численности работников железной дороги; доли прибывших молодых специалистов в общей численности работников дороги; а также снижение выбытия молодых специалистов, прибывших в отчетном году, по собственному желанию.

Реализация системного подхода к работе с молодыми специалистами на практике позволяет решить задачи, которые на первый взгляд кажутся почти несовместимыми (например, сформировать молодого амбициозного высококомпетентного сотрудника и при этом сохранить его лояльность компании).

\section{Список литературы}

1. Концепция долгосрочного социально-экономического развития Российской Федерации на период до 2020 года. Утвержден распоряжением Правительства РФ от 17 ноября 2008 г. [Электронный ресурс] № 1662-р. Доступ из справ.-правовой системы «Гарант-экспресс 2010».

2. Молодежный ресурс инновационного развития России. Проект. // Росмолодежь. [Электронный ресурс]. URL: http://www.fadm.gov.ru/agency/reports/733/ (дата обращения: 15.01.2010).

3. Концепция оптимизации системы социальной поддержки персонала ОАО «Российские железные дороги» на период 2008-2012 годы. Утвержден распоряжением ОАО «РЖД» от 31 мая 2008 г. № 1164 p.

UDC 331.108.44

keywords: the human capital, the youth, young experts, systematic work with young experts

V. A. Antropov, N. V. Dmitrenko

\title{
DEVELOPMENT OF INNOVATIVE POTENTIAL OF COMPANIES ON THE BASIS OF SYSTEMATIC WORK WITH YOUNG EXPERTS
}

Aggravation of competitive struggle in the context of globalization of socialandeconomic, politicalandcultural processes in the world puts forward competitiveness of an enterprise as a priority problem of management.
In modern market conditions the basic competitive advantage of a company is effective application of the human capital, and in the first place, the youth as the basic carrier of innovative potential of development. 
Authors consider organization of work with young experts from the point of view of a systematic approach. Development of innovative potential of a company on the basis of systematic work with young experts is also considered.

One of the basic resources of an organization causing its stability in the market environment, efficient functioning and prospect strategic development is human capital. Nowadays a considerable amount of theoretical researches is devoted to it. The concept of long-term social and economic development of the Russian Federation until 2020 shows that one of long-term system demands by the Russian economy in the middle of the current decade is human capital growth as a major factor of economic development [1, p.4].

Human capital management is the main problem, which top-managers and owners of the companies face. Various tendencies of human capital management provide its successful functioning in an organization. One of such major tendencies is work with young experts. It expands possibilities of innovative development of an organization at the expense of involving intellectual and creative potential of the youth while solving strategic problems and growth of professional and corporate competence of the youth.

D. Medvedev, the president of the Russian Federation, said in an opening address to the session of the State Council "On the youth policy of the Russian Federation" on 17, July, 2009: "We cannot develop a new technological society, which we are striving for so much, if we avoid participating of the youth in innovations".

Including systematic work with young experts into the general HRM (Human Resource Management) system is economically valid, due to threats regarding the human capital efficient development process:

- demographic situation in the country is close to ultimate (reduction of aggregate supply on the labour market due to decrease of able-bodied population by more than $10 \%$ in 2007-2020; reduction of supply on the labour market $-6,7 \%$ a year in 2011-2015 and $7,5 \%$ in 2016-2020) [1, p. 55];

- threats on the labour market (a real loss and inefficient use: general state of health of the youth, bad habits, high premature death rate, criminality; coordination between the education market and the labour market; mobility on the labour market) [2].

Owing to the above-stated, it is necessary to provide an updating process (a collective rejuvenation) on a constant systematic basis; to achieve participation of the youth in all processes; to develop innovative potential of the youth as one of the new factors of company growth; to direct energy of the youth to a channel of development and manufacture modernization.

By now, an experience in terms of work with the youth has been gained. Unfortunately, a great deal of authors consider particular issues of work with the youth and young experts (adaptation, development, motivation etc.), the application of which is carried out in mass practice, as a set of disconnected actions, which do not provide necessary systematic effect in the work with young experts.

We have carried out a research of systematic work with the staff of young experts at the "Sverdlovsk railways" - a branch of the joint-stock company "Russian Railways", a large public transport corporation. We selected the object of supervision firstly because of relative uniformity and stability of work parameters with young experts in structural railway divisions. The second reason of choosing is homology concerning other branches of the jointstock company «Russian Railways», giving the grounds to interpret the received regularities for a wide group of social and economic systems.

The joint-stock company "Russian Railways", founded by the governmental order of the Russian Federation №585 on 18, September, 2003, is included into a group of world three leaders of railway companies. Its establishment became the result of the first stage of reforming the railway industry according to the governmental order of the Russian Federation №384 of 18, May, 2001. Thus, from 2006 until 2010 the third stage of reforming has been taking place. The main objective of this stage is to create a developed competitive market in the field of rail transportation.

The distinguished features of the Company are: size (quantity of workers and turns); the branch network (in all the territory of Russia, including both megalopolises and settlements); historical background (the former state structure, under which the workers got accustomed to certain privileges and benefits), personnel policy on a priority basis (attractive conditions for young experts and experts for required positions) [3, p.10].

The "Sverdlovsk railways" is a powerful transport complex providing transport-economic links between industrial areas of the Urals and Western Siberia with central, eastern and western areas of Russia and foreign countries.

The "Sverdlovsk railways" isadjoined byabranched out network of access ways for industrial transport. It serves mining, transportation, metallurgical and wood industries, enterprises of mechanical engineering and building material production.

The market provided with transport services of the "Sverdlovsk railways" covers $10.5 \%$ of the territory of our country and $7.4 \%$ of the population of 
the country. The "Sverdlovsk railways" is the largest employer in the region. That is why its personnel selection and the policy concerning young experts have a great influence on the regional labour market.

The basic approach and principles of work with young experts in the Company are based on the Strategy of development of the railway transportation in the Russian Federation until 2030, the Strategy of development of personnel potential of the jointstock company «Russian Railways» until 2015 and the target program "The Youth of the "Russian Railways" company (2006-2010)".

Setting the management problems, we have to set an object of management first of all. We should be aware of some peculiarities when working with young experts. These peculiarities develop on the basis of specific conduct and positioning of young experts. One of the conditions of efficient work with this group of employees is understanding their strong and weak points and also having conditions for effective cooperation.

An average young expert a is a 23 year-old male, single, no children, graduated from the Urals State
University of Railway Transportation, belonging to the group of specialists.

Young railway experts are responsible, honest workers, aware of their own involvement in the combined effect. They also strive for carrying out their duties. Young experts admit that the knowledge obtained in the higher school does not always fit the demand to a position ( $34 \%$ of the respondents). That is why they have marked the tendency to proceed with their professional and personal advance. The respondents generally like the job at the "Sverdlovsk railways" $(83 \%)$.

According to the young experts, the job is stable (59\% of the respondents), promising (25\%), gives certain advantages - the opportunity to work according to the specialty (42\%) and to get certain privileges and social safeguards (Figure 1).

In 2009, most of the respondents said that their expectations concerning their jobs were mostly met (63\% of the respondents, which corresponds to the rate of 2008). Dependence of job attractiveness on a degree of justification of expectations was revealed (Figure 2).

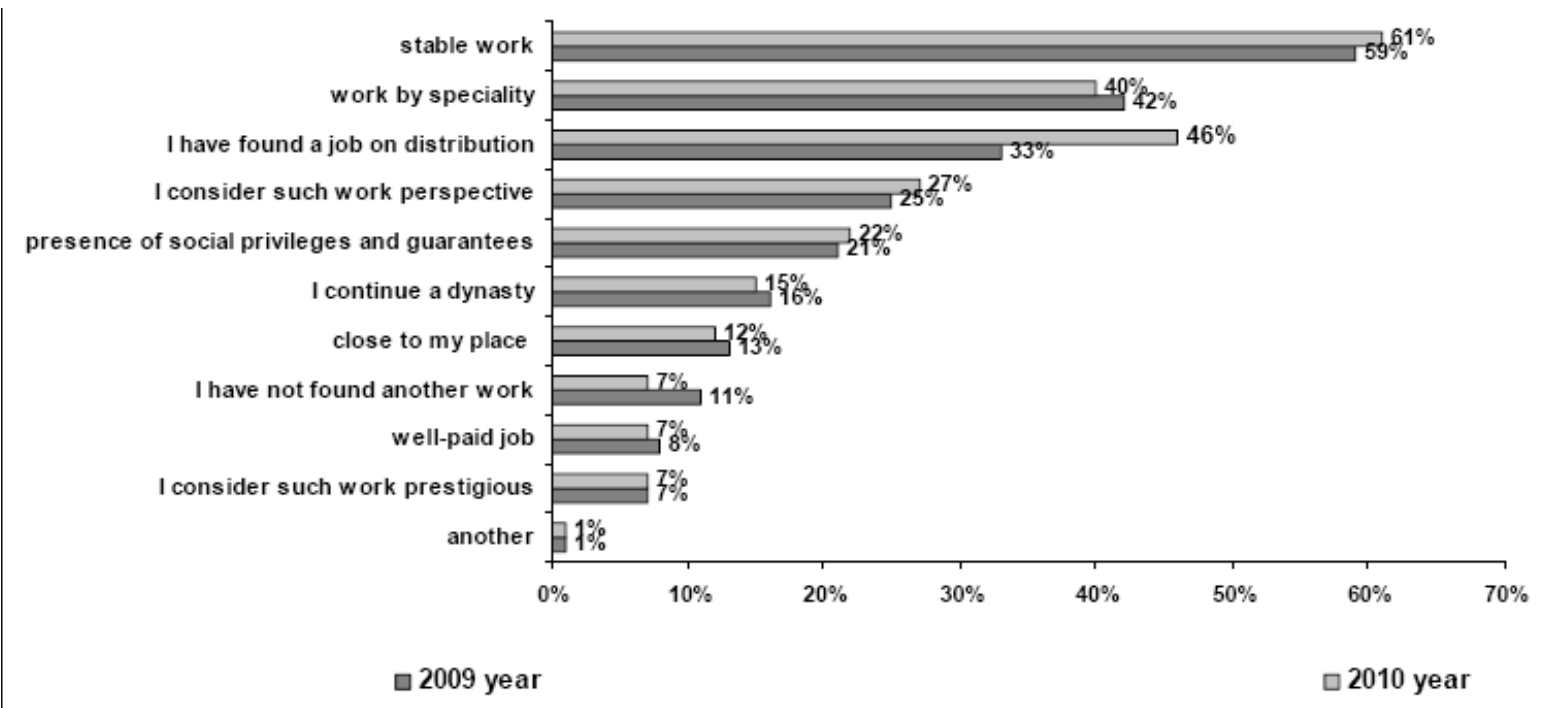

Fig. 1. Employment motivation by young experts at the railway company

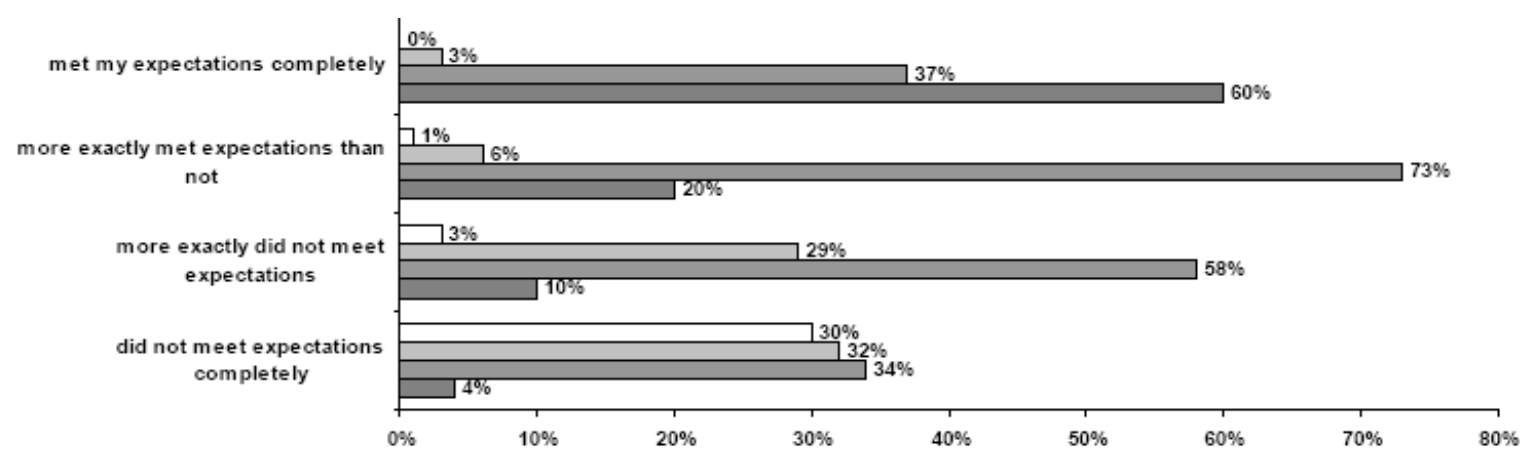

$\square$ yes, it is pleasant $\square$ more exactly it is pleasant than not $\square$ more exactly it is not pleasant than it is pleasant

Fig. 2. Dependence of job attractiveness on a degree of justification of young experts' expectations 


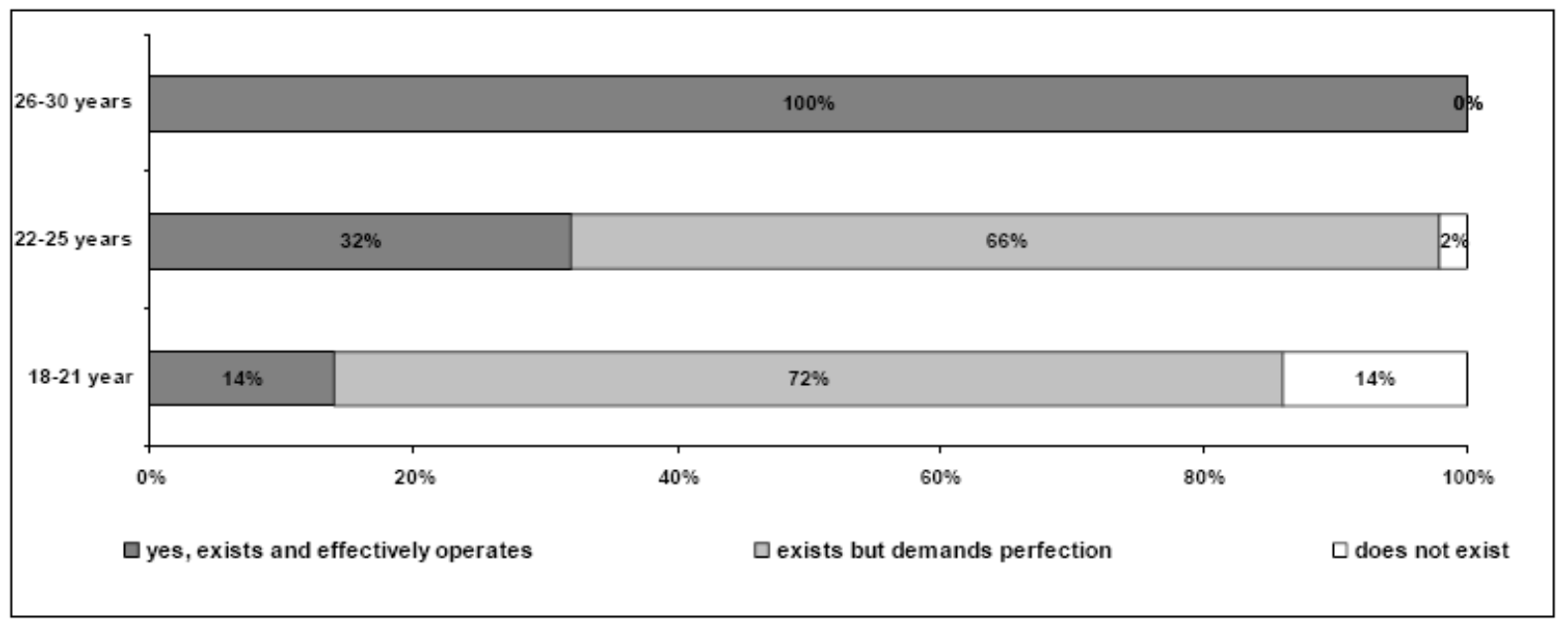

Fig. 3. Influence of an age of respondents on their opinion regarding the systematic work with young experts

According to interrogation of young experts of the joint-stock company «Russian Railways» in 2006 (3455 respondents), $56.9 \%$ of respondents confirmed effective systematic work with young experts at the enterprise. $28.6 \%$ of the respondents marked that systematic work with young experts is carried out only on paper. $8.4 \%$ of the respondents considered lack of systematic work with young experts at the enterprise. And $6.1 \%$ of the respondents did not hear about the systematic work with young experts. Unlike the young experts, the overwhelming majority of chiefs (1492 respondents have taken part in the interrogation) confirmed that systematic work with young experts was carried out on the premises $(92.1 \%)$.

Interrogation of young experts of the railway company (552 respondents) held in 2009 has shown that $82 \%$ of young experts had already confirmed availability of the systematic work with young experts (growth by 25,1\% compared to 2006).

The opinions of young experts graduated in 2009 were different depending on the age of respondents (Figure 3).

As you can see from the diagram, the younger the respondents, the more critical they are about the systematic work with young experts. It is quite explicable - the level of satisfaction with work in the $18-21$ age group is also lower than in the $26-30$ age group.

The survey showed that the development of the positive attitude of the young experts towards availability of the systematic work with young experts is influenced by the following factors: satisfaction with the youth policy; satisfaction with the possibility of further training; satisfaction with the working relationship with the supervisor; satisfaction with career opportunities.

Thus, the work with the youth should become an effective instrument of development and reorganization of the Company in the context of modernization of the society and growing requirements to the human capital.

It is possible under condition of development and consecutive realization of systematic work with young experts, focused on direct involvement of young experts in solving their own problems, and, on the other hand, solving global problems and the Strategy of development of the personnel potential of the company based on priority tendencies.

Similar work has been done at the "Sverdlovsk railways" - the branch of the joint-stock company «Russian Railways», and it has yielded specific results.

The analysis of the data about coming, application and leaving of young experts shows positive dynamics of work with young experts as part of an aggregate number of workers of the railways; of young expert coming as part of an aggregate number of workers of the railway; and also decrease in leaving at their own free will of those young experts who have come in the accounting year.

The realization of the system approach to work allows solving practically the problems, which at first sight seem almost incompatible (for example with young experts, to generate the young ambitions of a highly competent employee and thus to keep his or her loyalty to the company).

\section{References}

1. The concept of long-term social and economic development of the Russian Federation for the period until 2020 with the order of the Government of the Russian Federation of 17 November, 2008, № 1662-river. Retrieved from the referencelegal system "Hectare-WELT-EXPRESS TRAIN 2010".

2. A youth resource of innovative development of Russia. Project. Rosmolodezh: Retrieved from: http://www.fadm.gov. ru/agency/reports/733/ (reference date: 1/15/2010).

3 . The concept of optimization of social support of the personnel in the joint-stock company "Russian Railways" for 2008-2012: by the order of the joint-stock company "Russian Railways" of 31 May, 2008, № $1164 \mathrm{r}$. 